Louisiana State University

LSU Digital Commons

Faculty Publications

School of Animal Sciences

$9-15-2017$

\title{
Influence of two ovulation-inducing agents on the pituitary response and follicle blood flow in mares
}

\author{
Y. L. Boakari \\ UNESP-Universidade Estadual Paulista \\ J. C. Ferreira \\ University of Illinois at Urbana-Champaign \\ H. S. Canesin \\ UNESP-Universidade Estadual Paulista \\ D. L. Thompson \\ LSU Agricultural Center \\ F. S. Lima \\ University of Illinois at Urbana-Champaign
}

See next page for additional authors

Follow this and additional works at: https://digitalcommons.Isu.edu/animalsciences_pubs

\section{Recommended Citation}

Boakari, Y., Ferreira, J., Canesin, H., Thompson, D., Lima, F., Pantoja, J., \& Meira, C. (2017). Influence of two ovulation-inducing agents on the pituitary response and follicle blood flow in mares. Theriogenology, 100, 95-99. https://doi.org/10.1016/j.theriogenology.2017.05.032

This Article is brought to you for free and open access by the School of Animal Sciences at LSU Digital Commons. It has been accepted for inclusion in Faculty Publications by an authorized administrator of LSU Digital Commons.

For more information, please contact ir@lsu.edu. 


\section{Authors}

Y. L. Boakari, J. C. Ferreira, H. S. Canesin, D. L. Thompson, F. S. Lima, J. C.F. Pantoja, and C. Meira 


\title{
Influence of two ovulation-inducing agents on the pituitary response and follicle blood flow in mares
}

\author{
Y.L. Boakari a, b , J.C. Ferreira ${ }^{\text {c, d, * }}{ }^{*}$ H.S. Canesin ${ }^{\text {a }}$, D.L. Thompson Jr. ${ }^{\text {d }}$, F.S. Lima ${ }^{\text {, }}$, \\ J.C.F. Pantoja ${ }^{a}$, C. Meira ${ }^{a}$ \\ a Department of Animal Reproduction and Veterinary Radiology, School of Veterinary Medicine and Animal Science, UNESP, Botucatu, São Paulo, Brazil \\ ${ }^{\mathrm{b}}$ Gluck Equine Research Center, Department of Veterinary Science, University of Kentucky, Lexington, United States \\ ${ }^{\mathrm{c}}$ Department of Veterinary Clinical Medicine, College of Veterinary Medicine, University of Illinois, Urbana, IL, USA \\ ${ }^{\mathrm{d}}$ School of Animal Sciences, Louisiana State University Agricultural Center, Baton Rouge, LA, United States
}

\section{A R T I C L E I N F O}

\section{Article history:}

Received 6 February 2017

Received in revised form 24 May 2017

Accepted 30 May 2017

Available online 8 June 2017

\section{Keywords:}

LH

Deslorelin

hCG

Follicle vascularity

Doppler ultrasonography

\begin{abstract}
A B S T R A C T
The objective of the current study was to evaluate the effects of deslorelin and hCG, two ovulationinducing therapies, on LH surge and follicle vascularity in mares. Thirty mares were either treated with $1.5 \mathrm{mg}$ IM of deslorelin, 2,500 IU IV of hCG or $2 \mathrm{~mL}$ IM of NaCl $0.9 \%$ (GnRH, hCG and Saline groups, respectively). Power-flow Doppler examination and blood collection were performed every hour during the first 12 hours after treatment (H0) and every six hours between hours 12 (H12) and 30 (H30) after treatment. Moreover, endpoints were evaluated every hour through the last six hours before ovulation (OV-6 to OV-1). In GnRH group, plasma LH concentration progressively increased $(\mathrm{P}<0.001)$ during the first 6 hours after treatment and remained high $(\mathrm{P}>0.1)$ until OV-1. A significant increase in LH concentrations was first detected $(\mathrm{P}<0.05)$ at 24 hours after treatment in hCG group, while no changes $(\mathrm{P}>$ 0.1 ) on LH levels were found during $\mathrm{HO}-\mathrm{H} 30$ and between OV-6 and OV-1 in the Saline group. Independent of the treatment, significant variations on the percentage of the follicle wall with Doppler signals were not observed $(\mathrm{P}>0.1)$ throughout the entire experiment. A weak correlation between the preovulatory follicle vascularity and the plasma LH concentration was found in GnRH, hCG and Saline groups $(r=+0.29,+0.29$ and -0.23 , respectively; $\mathrm{P}<0.0001)$. These results described for the first time the immediate and continuous pituitary response to ovulation-inducing therapy with injectable deslorelin. Moreover, spontaneous and induced ovulations were not preceded by an increased follicle vascularity, which differs from previous reports in large animals.
\end{abstract}

Published by Elsevier Inc.

\section{Introduction}

Determining the most appropriate moment to perform natural or artificial mating is essential to maximize conception rates through the breeding season in mares [1]. However, the long physiologic duration of the equine estrus, when compared to other domesticated livestock [2-4], makes it difficult to accurately predict the time of ovulation [5]. Currently, the use of ovulation-inducing therapies [6] and the visualization of impending ovulation indicators by B-mode ultrasound examination [7] has been applied to ensure breeding at the appropriate time.

In mares, ovulation-inducing therapies with deslorelin or hCG

\footnotetext{
* Corresponding author. 1008 W Hazelwood Dr, Urbana, IL 61802, USA.

E-mail address: jair@illinois.edu (J.C. Ferreira).
}

stimulate the final maturation and the rupture of the follicular wall within $48 \mathrm{~h}[1,8,9]$. Deslorelin, a synthetic GnRH agonist $[1,10]$, acts on the adenohypophysis inducing the pulsatile release of endogenous LH and the subsequent ova maturation [11]. Differently, hCG binds to follicular $\mathrm{LH}$ receptors due to its structural similarity to the equine gonadotropin molecule [12,13], prompting an analogous LHactivity [14].

Transrectal Doppler ultrasonography has been recently used to study the blood flow of the follicle wall in mares [15,16], cattle $[17,18]$, ewes [19], canines [20], and women [21]. Changes in the ovarian vascular network during estrus allow the delivery of essential components for follicular maturation and steroidogenesis [22]. Therefore, Doppler ultrasonography has the potential to be an efficient real-time method for in vivo evaluation of the functional status of preovulatory follicles. However, the current literature remains unclear about the follicle hemodynamics during the 
impending ovulation phase in mares. Initial studies described an increased follicle vascularity through the preovulatory period $[16,23]$ followed by an abrupt decrease of the Doppler signals in the follicle wall during the last four hours before ovulation [7]. In contrast, the occurrence of ovulation apparently was not affected by the absence of changes on the follicular vascularity in mares treated with hCG [24] or recombinant equine LH [15]. Moreover, the effect of synthetic GnRH agonist agents on the blood flow of dominant follicles has not been described in mares.

Studies with cattle and mares have suggested a correlation between the LH surge and the blood-flow of follicles after ovulationinducing therapy [25-28]. Considering the distinct biologic activity of hCG and GnRH analogs on final follicular maturation, we have hypothesized that the hemodynamics of dominant follicles are dependent on the ovulation-inducing agent. Therefore, the primary purpose of the present study was to characterize the influence of treatment with hCG and deslorelin on the vascularity of preovulatory follicles in mares. The specific goals were: a) To describe the relationship between changes in the percentage of follicle wall with power-flow signals and the concentrations of LH during the impending ovulation phase, and b) to evaluate the effectiveness of Doppler technology for predicting spontaneous and induced ovulations in mares.

\section{Material and methods}

\subsection{Animals and experimental groups}

Thirty cycling mixed breed mares with 5-15 years of age, weighting $250-380 \mathrm{~kg}$, were used for the present study. Mares were handled in accordance with the Guide for Care and Use of Agricultural Animals in Agricultural Research and Teaching (protocol number 139/2012). The study was conducted during a single mid-breeding season (from January to March) in the Reproduction Center of the Department of Animal Reproduction and Veterinary Radiology at the São Paulo State University, Brazil (Latitude $22^{\circ} 53^{\prime}$ $09^{\prime \prime}$ and Longitude $48^{\circ} 26^{\prime} 4^{\prime \prime}$ ). All mares were maintained on grass hay, pelleted feed and trace mineralized salt with free access to water. The age of mares was estimated from dental characteristics [29]. Score for body condition was evaluated according to Henneke et al. (1983) and for all mares, it remained high (score $\geq 7$ ) during the experiment.

B-mode ultrasonography examination was done once a day to monitor follicular development. Mares showing a pre-ovulatory follicle $\geq 35 \mathrm{~mm}$ of diameter associated with endometrial edema were assigned into three experimental groups. The first group $(\mathrm{n}=10)$ received $\mathrm{GnRH}$ (1.5 $\mathrm{mg}$ of Deslorelin, IM); the second group $(\mathrm{n}=10)$ received hCG $(2500 \mathrm{IU}$ of $\mathrm{hCG}, \mathrm{IV})$; and third group $(\mathrm{n}=10)$ received a Saline $(1.5 \mathrm{~mL}$ of $\mathrm{NaCl} 0.9 \%$, IM) and served as a control group in our experiment. Only mares that ovulated between 30 and $48 \mathrm{~h}$ after treatment were used in the GnRH and hCG groups. All mares from the Saline group had spontaneous ovulation. Mares with double ovulations or anovulatory hemorrhagic follicles were not used in the study. The moment immediately before treatment was considered $\mathrm{HO}$.

\subsection{Data collection}

Blood collection and Doppler ultrasonography examination were performed to characterize the changes in plasma LH concentration and vascularity of the preovulatory follicle. Data collection was performed every one hour during the first $12 \mathrm{~h}$ of the study and every six hours from hours 12 (H12) to 30 (H30) after treatment. Additionally, endpoints were evaluated hourly from $\mathrm{H} 30$ until the detection of a corpus luteum (CL) in mares treated with GnRH or hCG. In the Saline group, mares were scanned with Bmode ultrasonography every $4 \mathrm{~h}$ from $\mathrm{H} 30$ to the visualization of impending ovulation signals within $12 \mathrm{~h}$. After that, endpoints were evaluated hourly, and mares that ovulated in less than $10 \mathrm{~h}$ were included in the study. Impeding ovulation was predictable by the combination of a thick and echogenic granulosa, decreased turgidity, loss of spherical shape, detached granulosa segments and echoic spots in the antrum [30-33].

\subsection{Doppler ultrasonography examination}

Vascularity of the preovulatory follicles was estimated using a pulsed-wave color Doppler ultrasound instrument (SONOACE PICO, Medison Brazil Ltda) equipped with a linear endocavitary transductor of 5-9 MHz (LV5-9CDn, $60 \mathrm{~mm}$ ). Doppler settings were maintained constant during the entire study. Power-flow mode function was used to display blood-flow signals from the vessels of the follicle wall. The entire follicle was scanned in a slow and continuous motion. Scans of $1 \mathrm{~min}$ were recorded in a portable computer equipped with a video capture device (Pinnacle Studio 9, Ottawa, ONT, Canada). The follicular vascularity of each film was posteriorly estimated by two independent operators blind to treatment or ovulation. A similar subjective methodology has been used for studying blood-flow of follicles in mares [16,34] and heifers [18]. The vascularity of preovulatory follicles was scored considering the percentage $(0 \%-100 \%)$ of follicle wall circumference with Doppler signals during the film clip analysis, as described previously for large animals $[7,18,24,34]$.

Supplementary video related to the Doppler ultrasonography examination of the follicle can be found at http://dx.doi.org/10. 1016/j.theriogenology.2017.05.032

\subsection{Plasma LH concentration}

Blood samples were collected immediately before each Doppler ultrasonography examination by jugular venipuncture into heparinized tubes for the measurement of plasma $\mathrm{LH}$ concentration. Blood was centrifuged $(1500 \times \mathrm{g} / 10 \mathrm{~min})$ and plasma was stored at $-20{ }^{\circ} \mathrm{C}$ until assayed.

Hormonal assays were performed in the School of Animal Sciences at Louisiana State University Agricultural Center, Baton Rouge, USA. Plasma samples were assayed by radioimmunoassay, as previously validated for mares [35]. The double-antibody assay was based on anti-equine chorionic gonadotropin primary antiserum generated in a rabbit and radio-iodinated ovine $\mathrm{LH}$ tracer. The intra- and inter-coefficient of variation were $3.2 \%$ and $7.0 \%$, respectively. The sensitivity of the assay was $0.4 \mathrm{ng} / \mathrm{mL}$.

\subsection{Statistical analysis}

The first part of the data was normalized to the moment immediately before treatment (Hour 0 ) and ended at Hour 30 . The last six hours before the CL visualization (OV-6 to OV-1) were used for retrograde statistical analysis of the ovulation-impending phase. A Shapiro-Wilk test was performed to visualize the normal distribution of the data. Mixed-model analysis for repeated measures (SAS PROC MIXED-Version 9.2 SAS Institute, Inc, Cary, NC) was used to compare the means of each response variable between groups and time and their interaction. Post hoc analyses were conducted using a Tukey test. No statistical differences between operators, among hours or an operator-by-hour interaction were 
detected $(\mathrm{n}=2 ; \mathrm{r}=0.72 ; \mathrm{P}>0.1$ ) for preovulatory follicles score. Therefore, the average was used for statistical analysis of bloodflow data. The level of significance was defined at 0.05. Data is presented as a mean \pm standard error of the mean.

\section{Results}

The interval from $\mathrm{HO}$ until CL detection was longer $(\mathrm{P}<0.001)$ in Saline group $(80.00 \pm 3.38 \mathrm{~h})$ than in GnRH and hCG groups $(40.06 \pm 1.05$ and $37.70 \pm 0.47 \mathrm{~h}$, respectively).

Effect of treatment $(P=0.002)$, hour $(P<0.001)$ and their interaction $(\mathrm{P}<0.001)$ was found for plasma $\mathrm{LH}$ concentration between $\mathrm{HO}$ and $\mathrm{H} 30$ (Fig. 1). In GnRH group, a progressive increase on LH concentration was observed during the first $6 \mathrm{~h}$ after treatment. A significant decrease $(\mathrm{P}<0.01)$ was detected from $\mathrm{H} 12$ to $\mathrm{H} 18$ (13.4 \pm 0.2 and $11.1 \pm 0.5 \mathrm{ng} \mathrm{mL}^{-1}$, respectively). However, the LH concentration remained higher $(\mathrm{P}<0.04)$ than the observed at $\mathrm{HO}\left(5.6 \pm 0.4 \mathrm{ng} \mathrm{mL}^{-1}\right)$ in mares treated with deslorelin. In hCG group, concentrations of $\mathrm{LH}$ remained low during the first $12 \mathrm{~h}$ post-treatment $(4.0 \pm 0.2 \mathrm{ng} \mathrm{mL}-1, \mathrm{P}>0.1)$ and a significant increase $(\mathrm{P}<0.001)$ was first detected at $\mathrm{H} 24\left(6.7 \pm 0.4 \mathrm{ng} \mathrm{mL}^{-1}\right)$. The plasma LH concentration did not change during the first $30 \mathrm{~h}$ posttreatment $\left(4.9 \pm 0.3 \mathrm{ng} \mathrm{mL}^{-1}, \mathrm{P}>0.1\right)$ in mares from Saline group. Also, LH levels remained constant $(\mathrm{P}>0.1)$ between OV-6 to OV-1 in mares treated with deslorelin, hCG or $\mathrm{NaCl} 0.9 \%$ from $(8.5 \pm 0.9$, $10.4 \pm 0.7$ and $12.7 \pm 0.9 \mathrm{ng} \mathrm{mL}^{-1}$, respectively; Fig. 2).

The mean concentration of $\mathrm{LH}$ in $\mathrm{GnRH}$ group was greater $(\mathrm{P}<0.05)$ than in hCG and Saline groups during the first $12 \mathrm{~h}$ after treatment $\left(11.2 \pm 0.7,4.01 \pm 0.2\right.$ and $4.6 \pm 0.3 \mathrm{ng} \mathrm{mL} \mathrm{m}^{-1}$, respectively). In addition, the $\mathrm{LH}$ concentration was greater in $\mathrm{GnRH}$ group than in hCG and Saline groups within the H5-H12 and H7-H9 intervals, respectively $(\mathrm{P}<0.01$, Fig. 1 ). However, no differences $(\mathrm{P}>0.1)$ between $\mathrm{GnRH}$ and hCG groups were detected for $\mathrm{LH}$ concentrations between $\mathrm{H} 12$ and $\mathrm{H} 30\left(8.3 \pm 0.8 \mathrm{ng} \mathrm{mL}^{-1}\right)$. Effect of treatment was not detected $(\mathrm{P}>0.1)$ for plasma LH concentration during the last six hours before ovulation (Fig. 2).

No effect of treatment, hour and their interaction $(P>0.05)$ was observed for the follicle vascularity during the first $30 \mathrm{~h}$ after treatment (Fig. 3) and during the last six hours before ovulation (Fig. 4). Based on examinations performed hourly or at each six hours no difference between groups $(P>0.1)$ was detected for follicle vascularity on $\mathrm{H} 0-\mathrm{H} 12(34.05 \pm 0.8 \%$, ranged from 10.0 to $87.5 \%$ ) and $\mathrm{H} 12-\mathrm{H} 30$ ( $37.1 \pm 1.5 \%$, ranged from 15.0 to $90.0 \%$ ). In addition, independent of the treatment, the vascularity of the preovulatory follicle remained constant and low (37.4 $\pm 1.5 \%$; $\mathrm{P}>0.1$ ) during the last six hours before ovulation. A weak correlation between the follicle vascularity and the plasma LH

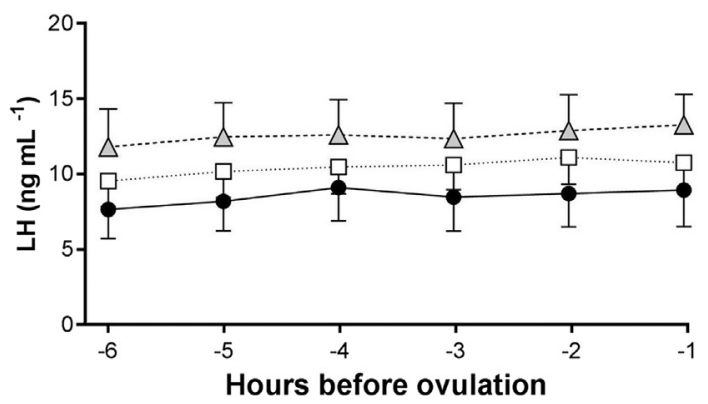

Fig. 2. Mean ( \pm s.e.m.) for plasma $\mathrm{LH}$ concentration $\left(\mathrm{ng} \mathrm{mL}^{-1}\right)$ in mares treated with $1.5 \mathrm{mg}$ of deslorelin $(\bullet), 2.500 \mathrm{IU}$ of hCG $(\square)$ or $2 \mathrm{~mL} \mathrm{NaCl} 0.9 \%$ ( $\boldsymbol{\Delta}$ ).

concentration was found from H0 to H30 in GnRH, hCG and Saline groups $(r=+0.29,+0.29$ and -0.23 , respectively; $P<0.0001)$.

\section{Discussion}

Doppler ultrasonography has become one of the best and most reliable techniques for in vivo evaluation and study of the ovarian hemodynamics in livestock $[15,18]$. The present study described for the first time the lack of association between the follicle vascularity and the LH surge before spontaneous or induced ovulation in cycling mares. Our findings allow the reevaluation of previous concepts considered definitive regarding the physiology of the final stages of follicular maturation in the species.

This is the first report of vascularity analysis of the equine preovulatory follicle using Power-flow imaging. The conventional Color-flow function has been originally used for general examinations of the ovarian hemodynamics in large animals [16]. However, due to its greater sensitivity to weak Doppler signals from vessels with small caliber and low blood flow [36], Power-flow function has recently been used in mares for direct analysis of the luteal tissue [37] and the endometrium [38,39]. Moreover, a similar approach was successfully applied to characterize the blood-flow of dominant follicles during estrus in cattle $[18,27]$.

A daily increase in vascularity of the dominant follicle as it matures before the first ovulation [16] and during the last portion [7] of the ovulatory season was previously reported in mares. However, despite the greater sensitivity of the current approach and the shorter interval between examinations, changes on follicle vascularity were not detected before ovulation in the present study. Under the current experimental conditions, our findings demonstrated that low and unchanged vascularity did not prevent the ovulatory capability of dominant follicles, contrasting the results

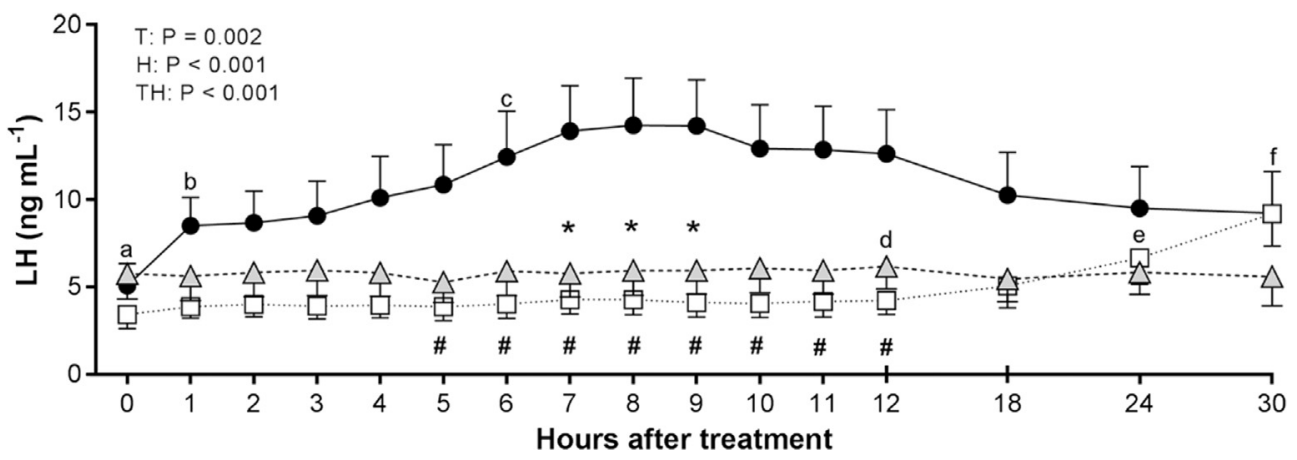

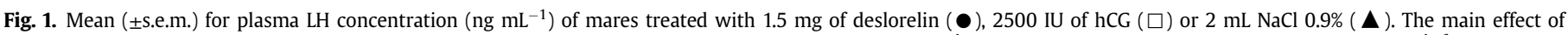

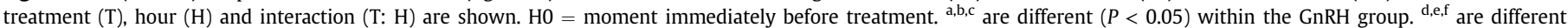

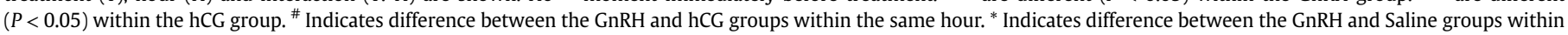
the same hour. 


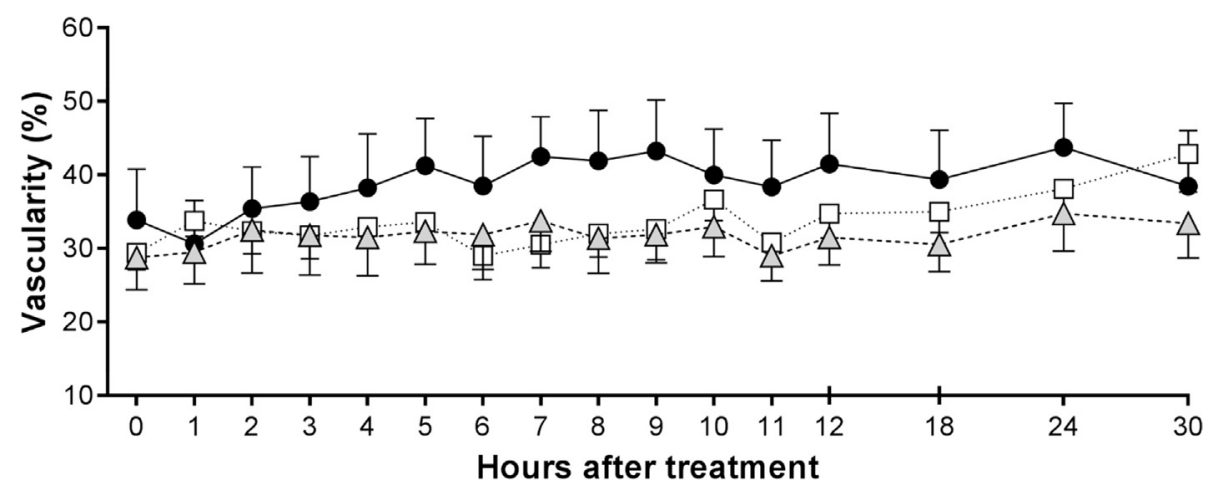

Fig. 3. Mean ( \pm s.e.m.) for vascularity of preovulatory follicles (\%) in mares treated with $1.5 \mathrm{mg}$ of deslorelin ( $)$ ), $2500 \mathrm{IU}$ of hCG ( $\square$ ) or $2 \mathrm{~mL}$ NaCl $0.9 \%$ ( $\boldsymbol{\Delta}$ ).

and interpretation suggested by Ref. [23]. In this regard, the establishment of pregnancy, but not the occurrence of ovulation, has been associated with a high percentage of follicle wall circumference with Doppler signals [24]. Moreover, the final maturation of the follicle has not been correlated with changes on its vascularity in mares later submitted to oocyte recovery procedures [16]. Additionally, ovulation failure has not been reported in synchronized beef cows with impaired follicle vascularity [40].

The final growth and maturation of the dominant follicle has been associated with an increased release of LH [41,42], reaching maximum concentration $24 \mathrm{~h}$ after spontaneous ovulation in mares $[11,43]$. The effect of ovulation-inducing agents on the plasma LH concentrations was expected due to the distinct biological activity between hCG [12-14] and deslorelin [11]. In the present study, the ovulation-inducing therapy with a GnRH analog triggered an immediate pituitary response as previously reported in cattle. However, a single peak of LH has been detected immediately after the administration of gonadorelin in heifers [27], while LH increased progressively over time and remained high until ovulation in mares treated with deslorelin. In contrast, a greater rate of increase in endogenous LH concentration was observed only 24 h after hCG treatment. The increase in $\mathrm{LH}$ response at a later time $(\mathrm{H} 30)$ was expected in mares from the hCG group. In addition to LH-activity on gonadal receptors [44-46], hCG induces a subsequent release of gonadotrophins when the dominant follicle reaches maturity $[45,47,48]$.

\section{Conclusion}

Under the current experimental conditions, a single ovulationinducing therapy with deslorelin or hCG induced a progressive LH rise without affecting the blood flow of dominant follicles. Our study demonstrated for the first time that a continuous and low

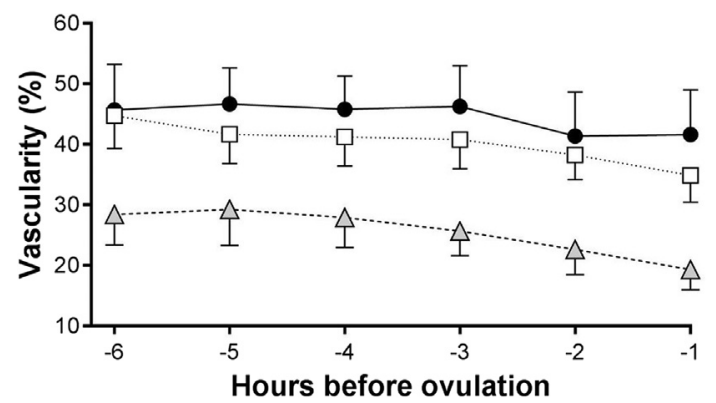

Fig. 4. Mean ( \pm S.e.m.) for vascularity of preovulatory follicles (\%) in mares treated with $1.5 \mathrm{mg}$ of deslorelin (•), $2.500 \mathrm{IU}$ of hCG $(\square)$ or $2 \mathrm{~mL} \mathrm{NaCl} 0.9 \%$ ( $\boldsymbol{\Delta}$ ). follicle vascularity did not prevent the occurrence of ovulation in mares. Therefore, the real-time analysis of the follicle wall with color Doppler signals did not assist in predicting the time of induced or spontaneous ovulation. The outcomes of a reduced vascularity of preovulatory follicles on the final stages of oocyte maturation and on the functionality of the subsequent $\mathrm{CL}$ must be investigated.

\section{Acknowledgments}

This work was supported by FAPESP (grant numbers 2012/ 11117-3, 2012/12288).

\section{References}

[1] McCue PM, Magee C, Gee EK. Comparison of compounded deslorelin and hCG for induction of ovulation in mares. J Equine Vet Sci 2007;27:58-61.

[2] Ginther O, Knopf L, Kastelic J. Temporal associations among ovarian events in cattle during oestrous cycles with two and three follicular waves. J Reprod Fertil 1989;87:223-30.

[3] Sartori R, Haughian J, Shaver R, Rosa G, Wiltbank M. Comparison of ovarian function and circulating steroids in estrous cycles of holstein heifers and lactating cows. J Dairy Sci 2004;87:905-20.

[4] Ginther O. Major and minor follicular waves during the equine estrous cycle. J Equine Vet Sci 1993;13:18-25.

[5] Buratini J, e Silva AAMR, Barros CMQ, Papa FO, Caldas MCS, Meira C. Follicular dynamics in Mangalarga mares. Equine Vet J 1997;29:7-11.

[6] Squires EL. Hormonal manipulation of the mare: a review. J Equine Vet Sci 2008;28:627-34.

[7] Gastal EL, Gastal MO, Ginther OJ. Relationships of changes in B-mode echotexture and colour-doppler signals in the wall of the preovulatory follicle to changes in systemic oestradiol concentrations and the effects of human chorionic gonadotrophin in mares. Reproduction 2006;131:699-709.

[8] Barbacini S, Zavaglia G, Gulden P, Marchi V, Necchi D. Retrospective study on the efficacy of hCG in an equine artificial insemination programme using frozen semen. Equine veterinary Educ 2000;12:312-7.

[9] Ferris RA, Hatzel JN, Lindholm AR, Scofield DB, McCue PM. Efficacy of deslorelin acetate (sucromate) on induction of ovulation in american quarter horse mares. J Equine Vet Sci 2012:32:285-8.

[10] Lindholm A, Bloemen E, Brooks R, Ferris R, McCue P. Comparison of deslorelin and buserelin in mares: LH response and induction of ovulation. Anim Reprod Sci 2010;121:68-70.

[11] Mumford EL, Squires EL, Jöchle E, Harrison LA, Nett TM, Trigg TE. Use of deslorelin short-term implants to induce ovulation in cycling mares during three consecutive estrous cycles. Anim Reprod Sci 1995;39:129-40.

[12] Bousfield GR, Liu W, Sugino H, Ward D. Structural studies on equine glycoprotein hormones. Amino acid sequence of equine lutropin beta-subunit. J Biol Chem 1987;262:8610-20.

[13] Wilson CG, Downie CR, Hughes JP, Roser JF. Effects of repeated hCG injections on reproductive efficiency in mares. J Equine Vet Sci 1990;10:301-8.

[14] Adams T, Horton M, Watson J, Adams B. Biological activity of luteinizing hormone ( $\mathrm{LH})$ during the estrous cycle of mares. Domest Anim Endocrino 1986;3:69-77.

[15] Altermatt JL, Marolf AJ, Wrigley RH, Carnevale EM. Effects of FSH and LH on ovarian and follicular blood flow, follicular growth and oocyte developmenta competence in young and old mares. Anim Reprod Sci 2012;133:191-7.

[16] Ginther O, Gastal E, Gastal M, Siddiqui M, Beg M. Relationships of follicle versus oocyte maturity to ultrasound morphology, blood flow, and hormone concentrations of the preovulatory follicle in mares. Biol Reprod 2007;77: 
202-8.

[17] Ginther O, Rakesh H, Hoffman M. Blood flow to follicles and CL during development of the periovulatory follicular wave in heifers. Theriogenology 2014;82:304-11.

[18] Siddiqui M, Almamun M, Ginther O. Blood flow in the wall of the preovulatory follicle and its relationship to pregnancy establishment in heifers. Anim Reprod Sci 2009;113:287-92.

[19] Oliveira ME, Feliciano MA, D'Amato CC, Oliveira LG, Bicudo SD, Fonseca JF, et al. Correlations between ovarian follicular blood flow and superovulatory responses in ewes. Anim Reprod Sci 2014;144:30-7.

[20] Bergeron LH, Nykamp SG, Brisson BA, Madan P, Gartley CJ. An evaluation of Bmode and color doppler ultrasonography for detecting periovulatory events in the bitch. Theriogenology 2013:79:274-83.

[21] Costello MF, Shrestha SM, Sjoblom P, McNally G, Bennett MJ, Steigrad SJ, et al. Power doppler ultrasound assessment of the relationship between age and ovarian perifollicular blood flow in women undergoing in vitro fertilization treatment. J Assist Reprod Genet 2006;23:359-65.

[22] Watson E, Al-Zi'abi M. Characterization of morphology and angiogenesis in follicles of mares during spring transition and the breeding season. Reproduction 2002:124:227-34.

[23] Acosta T, Beg M, Ginther O. Aberrant blood flow area and plasma gonadotropin concentrations during the development of dominant-sized transitional anovulatory follicles in mares. Biol Reprod 2004;71:637-42.

[24] Silva L, Gastal E, Gastal M, Beg M, Ginther O. Relationship between vascularity of the preovulatory follicle and establishment of pregnancy in mares. Anim Reprod 2006;3:339-46.

[25] Acosta TJ, Hayashi K, Ohtani M, Miyamoto A. Local changes in blood flow within the preovulatory follicle wall and early corpus luteum in cows. Reproduction 2003;125:759-67.

[26] Ginther O, Beg M, Gastal E, Gastal M, Cooper D. Treatment with human chorionic gonadotropin (hCG) for ovulation induction is associated with an immediate $17 \beta$-estradiol decrease and a more rapid LH increase in mares. Anim Reprod Sci 2009;114:311-7.

[27] Siddiqui M, Ferreira J, Gastal E, Beg M, Cooper D, Ginther O. Temporal relationships of the LH surge and ovulation to echotexture and power doppler signals of blood flow in the wall of the preovulatory follicle in heifers. Reprod Fertil Dev 2010;22:1110-7.

[28] Aslan S, Arslanbas D, Beindorff N, Bollwein H. Effects of induction of ovulation with GnRH or hCG on follicular and luteal blood flow in Holstein-Friesian heifers. Reprod Domest Anim 2011;46:781-6.

[29] Manual AAoEP. Official guide for determining the age of the horse. Lexington, KY: AAEP; 2002.

[30] Pierson R, Ginther O. Ultrasonic evaluation of the preovulatory follicle in the mare. Theriogenology 1985;24:359-68.

[31] Carnevale E, McKinnon A, Squires E, Voxx J. Ultrasonographic characteristics of the preovulatory follicle preceding and during ovulation in mares. J Equine Vet Sci 1988;8:428-31.

[32] Townson D, Pierson R, Ginther O. Characterization of plasma progesterone concentrations for two distinct luteal morphologies in mares. Theriogenology
1989;32:197-204

[33] Gastal E, Gastal M, Ginther O. The suitability of echotexture characteristics of the follicular wall for identifying the optimal breeding day in mares. Theriogenology 1998;50:1025-38.

[34] Siddiqui M, Gastal E, Gastal M, Beg M, Ginther O. Effect of hCG in the presence of hCG antibodies on the follicle, hormone concentrations, and oocyte in mares. Reprod Domest Anim 2009;44:474-9.

[35] Thompson D, Godke R, Squires E. Testosterone effects on mares during synchronization with altrenogest: $\mathrm{FSH}$, LH, estrous duration and pregnancy rate. J Anim Sci 1983;56:678-86.

[36] Ginther O, Utt MD. Doppler ultrasound in equine reproduction: principles, techniques, and potential. J Equine Vet Sci 2004;24:516-26.

[37] Romano RM, Ferreira JC, de Siqueira Canesin H, Boakari YL, Ignácio FS, Novaes Filho LF, et al. Characterization of luteal blood flow and secretion of progesterone in mares treated with human chorionic gonadotropin for ovulation induction or during early diestrus. J Equine Vet Sci 2015;35:591-7.

[38] Ferreira J, Canesin HdS, Ignácio FS, Rocha NS, Pinto CR, Meira Cd. Effect of age and endometrial degenerative changes on uterine blood flow during early gestation in mares. Theriogenology 2015;84:1123-30.

[39] Ferreira JC, Ignácio FS, Rocha NS, Thompson DL, Pinto CR, Meira Cd. Real-time characterization of the uterine blood flow in mares before and after artificial insemination. Anim Reprod Sci 2015;160:90-6.

[40] de Tarso S, Gastal G, Bashir S, Gastal M, Apgar G, Gastal E. Follicle vascularity coordinates corpus luteum blood flow and progesterone production. Reprod Fertil Dev 2017;29:448-57.

[41] Freedman L, Garcia M, Ginther O. Influence of photoperiod and ovaries on seasonal reproductive activity in mares. Biol Reprod 1979;20:567-74.

[42] Gastal E, Gastal M. Equine preovulatory follicle: blood flow changes, prediction of ovulation and fertility. Rev Bras Reprod Anim 2011;35:239-52.

[43] Schauer SN, Guillaume D, Decourt C, Watson ED, Briant C, Donadeu FX. Effect of luteinizing hormone overstimulation on equine follicle maturation. Theriogenology 2013;79:409-16.

[44] Evans J, Roser J, Mikuckis G. Comparison of the interaction of equine LH and human chorionic gonadotrophin to equine testicular receptors. J Reprod Fertil Suppl 1981;32:113-21.

[45] Manau D, Fábregues F, Arroyo V, Jiménez W, Vanrell JA, Balasch J. Hemodynamic changes induced by urinary human chorionic gonadotropin and recombinant luteinizing hormone used for inducing final follicular maturation and luteinization. Fertil Steril 2002;78:1261-7.

[46] Fay J, Douglas R. Changes in thecal and granulosa cell LH and FSH receptor content associated with follicular fluid and peripheral plasma gonadotrophin and steroid hormone concentrations in preovulatory follicles of mares. J Reprod Fertil Suppl 1986;35:169-81.

[47] Briant C, Ottogalli M, Guillaume D. Attempt to control the day of ovulation in cycling pony mares by associating a GnRH antagonist with hCG. Domest Anim Endocrinol 2004;27:165-78.

[48] Evans M, Gastal E, Silva L, Gastal M, Kitson N, Alexander S, et al. Plasma LH concentrations after administration of human chorionic gonadotropin to estrous mares. Anim Reprod Sci 2006:191-4. 